\title{
SPATIAL VARIATIONS OF RADIOCARBON IN THE COASTAL AQUIFER OF ISRAEL-INDICATORS OF OPEN AND CLOSED SYSTEMS
}

\author{
Debbie Bruce $^{1,2} \bullet$ Gerald M Friedman $^{2} \bullet$ Aaron Kaufman $^{3} \bullet$ Yoseph Yechieli $^{1}$ \\ ABSTRACT. The spatial variation in radiocarbon concentration was studied in the Coastal Aquifer of Israel. Lower concen- \\ trations were found in the western section of the aquifer (55-70 pMC) as compared to the eastern section (80-100 pMC). \\ Since no correlation was found between the tritium and radiocarbon values, these variations could not simply be explained by \\ a difference in ages, or by a difference in the degree of old calcite dissolution as similar $\delta^{13} \mathrm{C}$ values were found throughout \\ the aquifer. The results are best explained when viewing the differences in ${ }^{14} \mathrm{C}$ values within the same coastal aquifer, where \\ the eastern section of the aquifer is a more open system and the western section is a more closed system. In general, the age \\ of the groundwater in the coastal aquifer was found to be less than 50 years old $\left({ }^{14} \mathrm{C}>55\right.$ and measurable tritium).
}

\section{INTRODUCTION}

One of the main issues that must be addressed when dating groundwater, is the estimation of the initial radiocarbon value. This topic has been examined in many different research studies (e.g. Dorr et al. 1987; Leany and Allison 1986; Geyh and Wirth 1980), that were unsuccessful in determining a universal solution. Various initial values are applied to different parts of the world and for different locations. The accepted values of initial ${ }^{14} \mathrm{C}$ in recent groundwater are between 60 and $100 \mathrm{pMC}$; however, these values are not well constrained. The distinction between open and closed systems within the groundwater network is one of the main factors in evaluating the initial ${ }^{14} \mathrm{C}$ value of the groundwater.

In an open system the carbonate is dissolved by water, which is in continuous contact with the $\mathrm{CO}_{2}$ reservoir at a fixed partial pressure (Mook 1980). The bicarbonate is expected to equilibrate with the soil $\mathrm{CO}_{2}$ in the unsaturated zone and to thereby stay in contact with the dominant soil $\mathrm{CO}_{2}$ exchange reservoir. The expected ${ }^{14} \mathrm{C}$ value for these conditions would be approximately $100 \mathrm{pMC}$ with a $\delta^{13} \mathrm{C}$ of approximately $-15 \%$ (expected fractionation of approximately 9\%o; Clark and Fritz 1997).

In a closed system, the descending water is cut off from the atmosphere and isolated from the soil $\mathrm{CO}_{2}$. Therefore, the dissolution of old carbonate is expected to lower the initial values of the ${ }^{14} \mathrm{C}$ and to enrich the $\delta^{13} \mathrm{C}_{\text {DIC }}$ by the mixing of soil DIC with marine carbonate $\left(\delta^{13} \mathrm{C} \cong 0 \%\right.$; Clark and Fritz 1997). It is believed that in nature the carbonate dissolution will occur under mixed conditions (Mook 1980).

As will be discussed below, the boundary between the open and closed system has most commonly been placed at the intersection of the saturated with the unsaturated zone and at the intersection of the phreatic with the confined part of an aquifer.

The goal of this research is to gain a better understanding of the spatial variations of the ${ }^{14} \mathrm{C}$ values in the Coastal aquifer of Israel by evaluating the factors that affect the initial ${ }^{14} \mathrm{C}$ value in this aquifer. The present research examines the aquifer as a whole unit in order to study its large-scale variations in ${ }^{14} \mathrm{C}$.

\footnotetext{
${ }^{1}$ Geological Survey of Israel, Jerusalem 95501, Israel. Email: yechieli@ mail.gsi.gov.il.

${ }^{2}$ Brooklyn College and Graduate School of the City University of New York, c/o Northeastern Science Foundation, P.O. Box 746, Troy, New York 12181-0746, USA

${ }^{3}$ Weizmann Institute of Science, Rehovot 76100, Israel
}

(C) 2001 by the Arizona Board of Regents on behalf of the University of Arizona Radiocarbon, Vol 43, Nr 2B, 2001, p 783-791

Proceedings of the 17 th International ${ }^{14} \mathrm{C}$ Conference, edited by I Carmi and $\mathrm{E}$ Boaretto 


\section{THE COASTAL PLAIN AQUIFER OF ISRAEL}

The Coastal Aquifer of Israel, which has a large storage capacity, and serves as the source for $25 \%$ of Israel's drinking water supply, is considered a very important natural resource for the country. The typical conditions of the coastal aquifer are currently being influenced by intensive pumping and artificial recharge in order to maximize its water utilization capabilities. The setting of the aquifer thirty years ago was more reflective of its natural conditions. Therefore, this study concentrates on the data gathered in the 1970s, while current results are used only for auxiliary purposes.

\section{Hydrogeology}

The Coastal Plain Aquifer of Israel extends along the coast of the Mediterranean Sea. The aquifer is made up of several depositional cycles from the Quaternary glacial and interglacial periods, comprising the Kurkar Group. The Plio-Pleistocene sand and calcareous sandstone of the aquifer is interbedded with marine and continental clay, silt, and shale lenses which represent the different periods of sea water transgressions and regressions of the Pleistocene (Issar 1968). The western part of the aquifer is mainly calcareous sandstone interbedded with marine clay, while the eastern part is mainly loam, red sand and sandstone (Gvirtzman et al. 1984). Beneath the Kurkar group is the Yafo formation of the Saqiya group, which is composed of impermeable marine clays and shales of Pliocene age (Figure 1). The thickness along the coast reaches up to 200 meters, and thins towards the eastern sections.

Due to the clay lenses, mainly near the coast, the aquifer can be divided into several sub-aquifers (Figure 1), the lower ones being confined. These lenses, which form the hydraulic barriers between the sub-aquifers, may cause variant chemical and isotopic compositions for the waters found between them (Nativ and Weisbrod 1994). Nevertheless, the natural flow of groundwater in the aquifer is from the Judean Mountains in the east to the Mediterranean Sea in the west. No major faults, which could effect the flow pattern, are known in the aquifer. The average transport time of water in the aquifer was calculated, using the hydraulic parameters of the aquifer, to be approximately 30 years, although in some specific regions the transport time can be more than 500 years (Mercado et al. 1975). The climate in the aquifer region is Mediterranean with an average precipitation of $500 \mathrm{~mm}$ per year.

\section{METHODS}

\section{Sampling}

Samples were collected from pumping wells along the Coastal Aquifer area (Figure 2). Most of the samples were obtained from depth of 50-100 m, from the B sub-aquifer or at places where the aquifer is not divided to several sub-aquifers. Some of these wells were resampled in the period between 1993 and 1998. $\mathrm{BaCl}_{2}$ solution was added to the samples, collected in 1974 , together with $\mathrm{NaOH}$ in order to precipitate the carbonates for ${ }^{14} \mathrm{C}$ and $\delta^{13} \mathrm{C}$ analysis. The samples taken in the $1990 \mathrm{~s}$ were put in sealed containers for isotopic analysis. A total of approximately $90-100 \mathrm{~L}$ of sample, which was to be used for the extraction of $\mathrm{CO}_{2}$, was collected from the wells using 20-L containers. One liter of sample was collected in a plastic bottle for tritium analysis.

\section{Analytical Procedure}

The Ba-carbonate of the 1974 samples was treated with acid to obtain the $\mathrm{CO}_{2}$ for the ${ }^{14} \mathrm{C}$ and $\delta^{13} \mathrm{C}$ analyses. The ${ }^{14} \mathrm{C}$ concentration was measured by means of proportional counters on ethane produced from the extracted $\mathrm{CO}_{2}$, with a counting uncertainty of $1 \mathrm{pMC}$. The water from the containers 


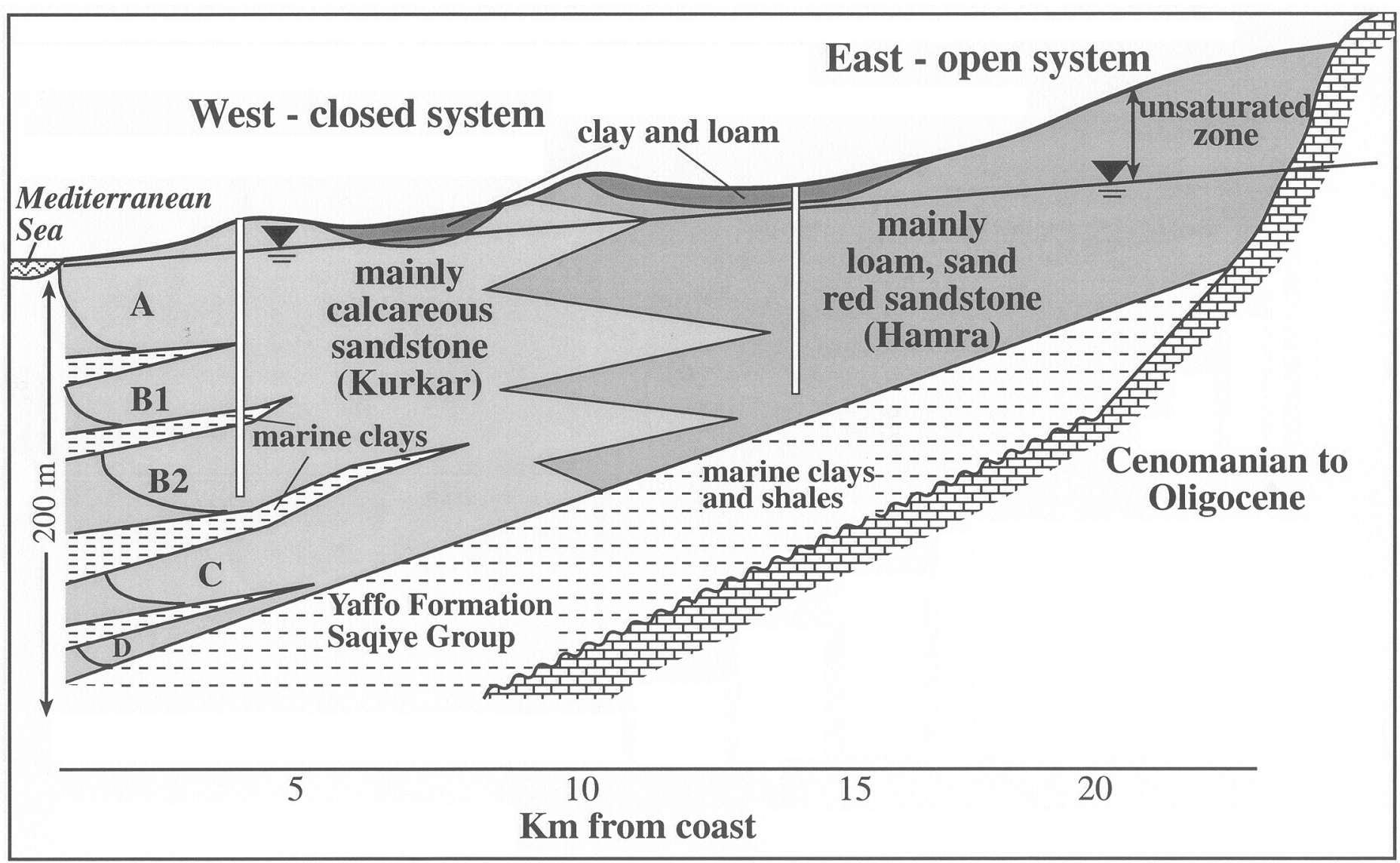

Figure 1 Schematic hydrogeological cross-section of the coastal plain aquifer of Israel. 


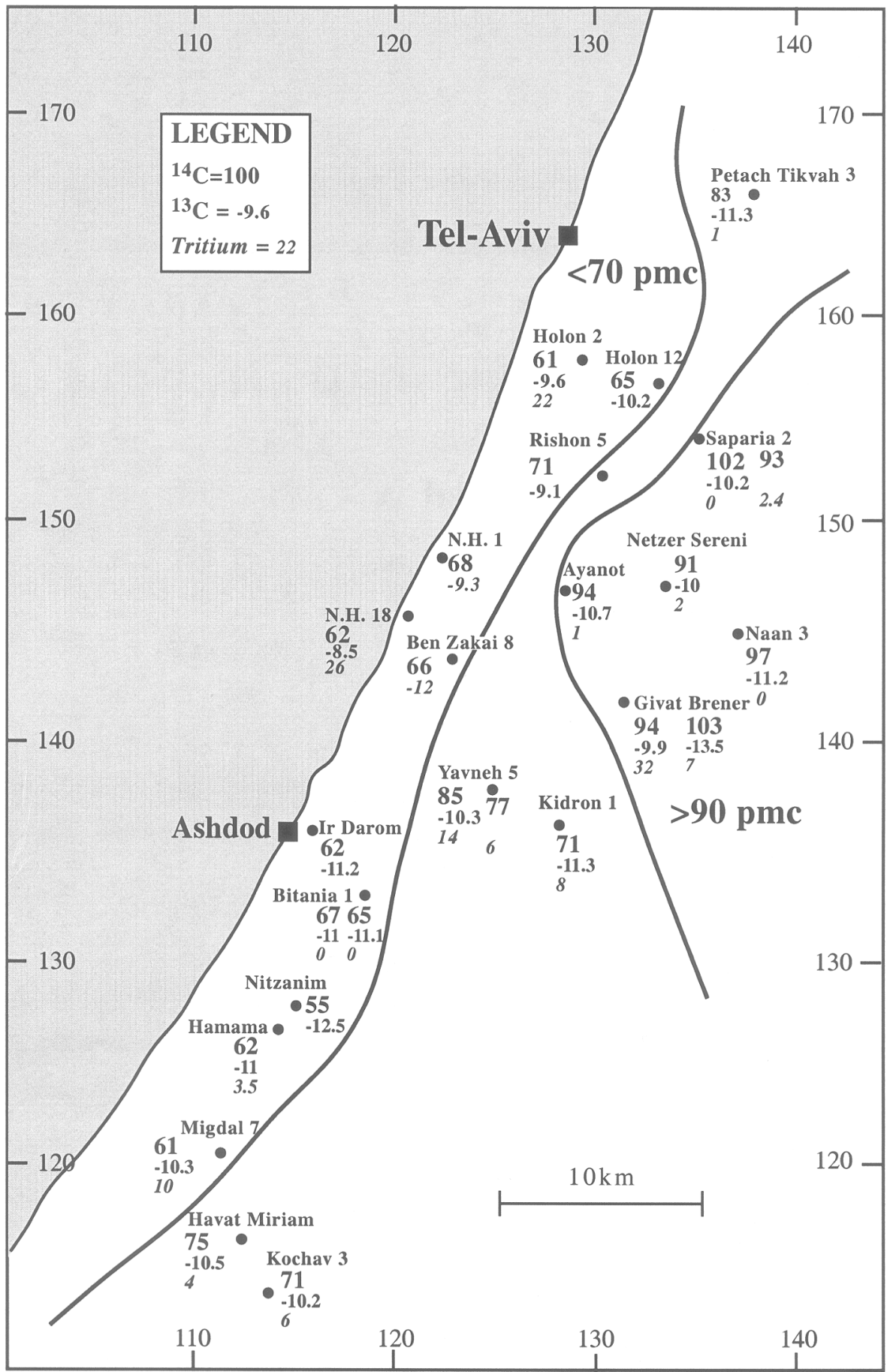

Figure 2 Location map of wells sampled during the present study. The solid line denotes concentration (higher than $90 \mathrm{pMC}$ in the east and lower than $70 \mathrm{pMC}$ in the west) 
of the 1990s samples was transferred to a 100-L sealed container designed to extract and trap the $\mathrm{CO}_{2}$ gas as a precipitate in a sodium hydroxide solution through the addition of $32 \%$ hydrochloric acid. The extraction was done within $48 \mathrm{hr}$ of sampling. The samples were analyzed for ${ }^{14} \mathrm{C}$ at the Weizmann Institute using a LKB 1220 Quantulus scintillation counter with a maximal error of $0.5 \mathrm{pMC}$, and for $\delta^{13} \mathrm{C}$ using a mass spectrometer with a maximal error of $0.1 \%$. Tritium analyses were also conducted at the Weizmann Institute, using a Quantulus scintillation counter with a maximal error of 1 T.U. in the 1970s and 0.2 T.U. in the 1990s.

\section{RESULTS}

Results of ${ }^{14} \mathrm{C}$ analyses sampled in 1974 showed a distinction between the eastern section of the aquifer where ${ }^{14} \mathrm{C}$ concentrations were above 90 , and the western section where ${ }^{14} \mathrm{C}$ values were less than $70 \mathrm{pMC}$ (Figure 2). Intermediate ${ }^{14} \mathrm{C}$ values were found in the central part of the aquifer. $\delta^{13} \mathrm{C}$ values were found to be relatively uniform throughout the aquifer (around $-11 \%$, Figure 3 ). No correlation was found between ${ }^{14} \mathrm{C}$ values and tritium concentration (Figure 3 ).

\section{DISCUSSION}

The differences in ${ }^{14} \mathrm{C}$ values cannot be interpreted simply as if they represent a difference in groundwater age. Such a simplified age calculation would yield a difference of several thousand years between east and west which is supported by neither the hydraulic ages nor the tritium content. The tritium concentrations do not show a significant difference between east and west (Figure 3) and, therefore, no significant age difference is indicated. Another possible explanation of the lower ${ }^{14} \mathrm{C}$ values in the west could be due to the increased dissolution of old carbonate in this section of the aquifer. However, such an explanation would require the $\delta^{13} \mathrm{C}$ values to be more positive in the west since more of the carbonate is of marine origin which has $\delta^{13} \mathrm{C}$ values close to zero. The results of this study, however, show relatively uniform $\delta^{13} \mathrm{C}$ values throughout the aquifer.

A more comprehensive explanation is that the eastern part of the coastal aquifer behaves more like an open system than does the western part. In such a case, the ${ }^{14} \mathrm{C}$ values in the eastern section remain close to the high values in the soil atmosphere while the $\delta^{13} \mathrm{C}$ concentrations reach values of $-15 \%$ and higher due to fractionation. On the other hand, the western section of the aquifer behaves as a closed system in which similar $\delta^{13} \mathrm{C}$ values (around -12\%o) are found due to dissolution of old carbonate, a process that is also responsible for lowering ${ }^{14} \mathrm{C}$ values. This explanation does not contradict the large variation in the tritium values without a significant difference between the eastern and western sections. These tritium values are determined by the specific recharge conditions at each sampling point, which may include, in some cases, mixing of several water bodies with different values. Such mixing could also be responsible for some of the variations in ${ }^{14} \mathrm{C}$ values, accounting for mixing between groundwater from different sub-aquifers and of different ages.

The variation in the degree of openness of the coastal aquifer system is supported by lithological properties, whereby the eastern section consists of a less-cemented sandstone than does the western section (Gvirtzman et al. 1984; Rosensaft et al. 1997). The existence of the marine clay layer in the west also contributes to the theory that a more closed system exists in the west relative to the east.

This explanation shows that, despite the spatial differences in ${ }^{14} \mathrm{C}$ and $\delta^{13} \mathrm{C}$ concentrations, groundwater in both areas of the aquifer is young. The tritium values in most of the groundwater, which are significantly higher than zero, indicate that the transit time is $<40 \mathrm{yr}$. There are a few exceptions, such as the Bitania well, where no tritium was found, implying a longer transit time. The young ages imply that the initial ${ }^{14} \mathrm{C}$ values were influenced by nuclear tests, at least in the eastern part of the aquifer. 

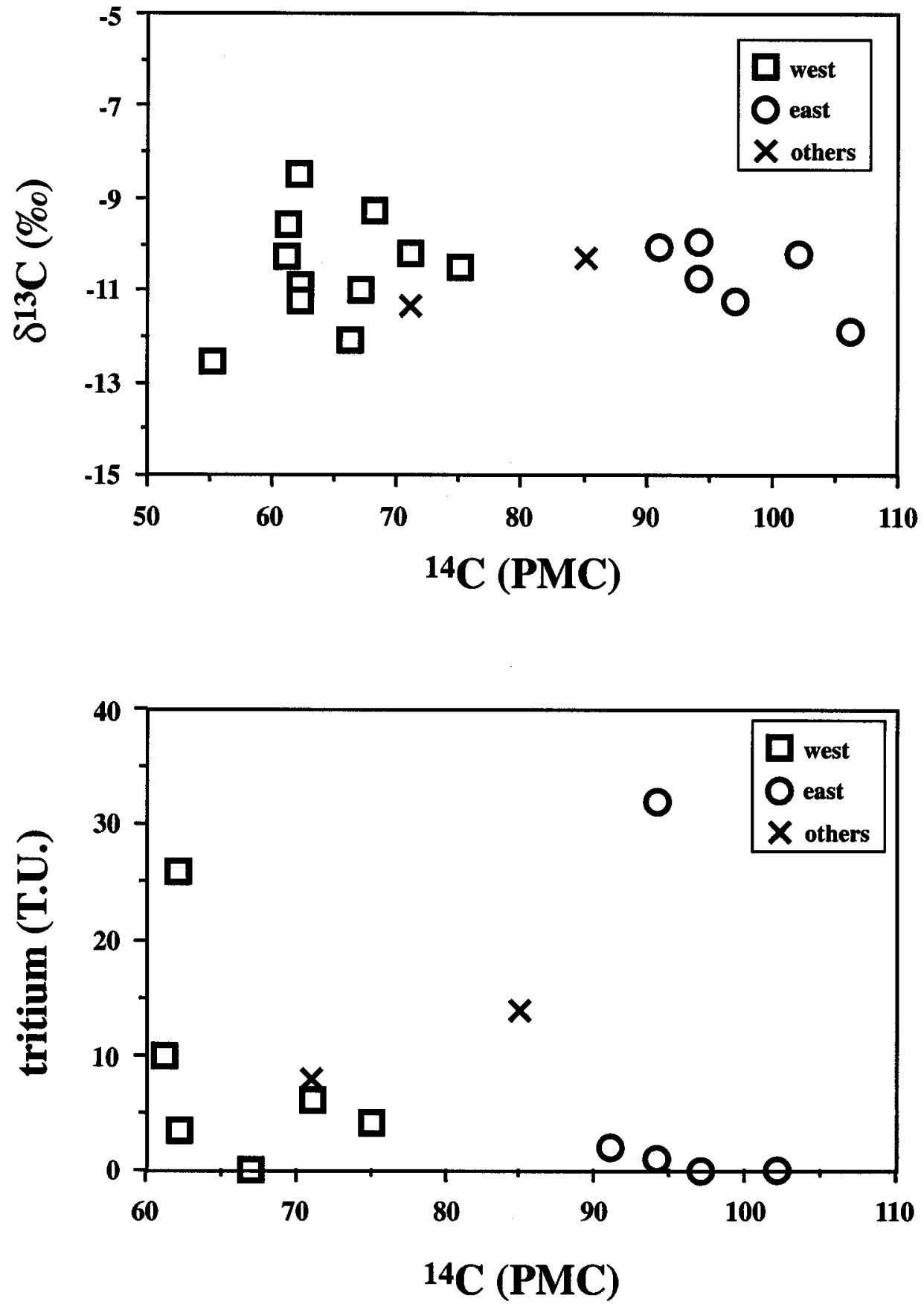

Figure $3{ }^{14} \mathrm{C}$ versus tritium and ${ }^{13} \mathrm{C}$ in groundwater in the coastal aquifer 
In many research studies, the unsaturated zone is considered an open system while the saturated zone is regarded as a closed system (e.g. Clark and Fritz 1997; Dorr et al. 1987; Wigley 1975). It can be argued, however, that the line between open and closed systems is not necessarily drawn between the unsaturated and saturated zones. A closed system may also begin within the unsaturated zone itself, depending on the type of sediments involved and the flow of the groundwater system. In some cases, the phreatic part of the aquifer is considered to be the open system, while the confined part the closed system. The present study is of an aquifer which is basically phreatic, yet is partly an open system and partly a closed one.

\section{Repetition of Analysis}

The repetition of an analysis may add information and/or strengthen the first analysis. An important use of such repetition is in improving the determination of groundwater ages. Determination of groundwater age requires an estimation of the dilution factor ( $\mathrm{Q}$ factor) that considers the dilution by dead carbon. The following equation can be given for an adjusted ${ }^{14} \mathrm{C}$ age (Wigley 1975):

$$
\mathrm{A}=\mathrm{QA}_{\mathrm{o}} 2^{-\mathrm{t} / \mathrm{T}}
$$

where $\mathrm{A}$ is the measured ${ }^{14} \mathrm{C}$ activity, $\mathrm{Q}$ is the dilution factor, $\mathrm{A}_{\mathrm{o}}$ is the activity at time zero, $\mathrm{t}$ is the age and $\mathrm{T}$ is the half-life.

The following paragraph describes a procedure which utilizes the tritium curve (Figure 4) in order to determine the $\mathrm{Q}$ factor for a given well. This method requires sampling of groundwater from the same location at least twice with a large difference in time between the two sampling periods. The following example of the Givat Brener well is given as an illustration of this method of calculation. Because of the sharp rise and fall of the rain tritium in 1962-1968, the tritium value of 32 T.U. obtained in the Givat Brener well in 1974 could indicate either an age of 1-2 years or of 12-14 years (Figure 4). Similarly, the value in 1997 (7 T.U.) indicates an age of either 12-24 or 38-40 years (Figure 4). Combining the values from both sampling periods, it seems that the groundwater age is in the range of $12-14$ years old. The ${ }^{14} \mathrm{C}$ value for this well in 1974 was $94 \mathrm{pMC}$. The ${ }^{14} \mathrm{C}$ value in the troposphere in 1962 (12 years earlier) was 120-140 pMC (Levin et al. 1980). The Q factor for this area is, therefore, 0.72 (94/130). Using this value to correct the dilution factor, it is possible to calculate the age of groundwater in the coastal aquifer.

This correction value may include additional effects beside dissolution of carbonate with dead carbon along the flow path. One factor that should be considered is the mixing of organic sources from several different years in the soil, which would cause the ${ }^{14} \mathrm{C}$ of the soil atmosphere to differ from that of the atmosphere. Depending on the ${ }^{14} \mathrm{C}$ levels in the atmosphere, the soil ${ }^{14} \mathrm{C}$ could be higher or lower than that of the atmosphere.

The above calculation is only a simplified illustration. Changes in the hydrological regime and the mixing of groundwater of different ages transforms this coastal aquifer into a more complex model which supersedes a simple calculation. 
Figure 4 Tritium concentrations in

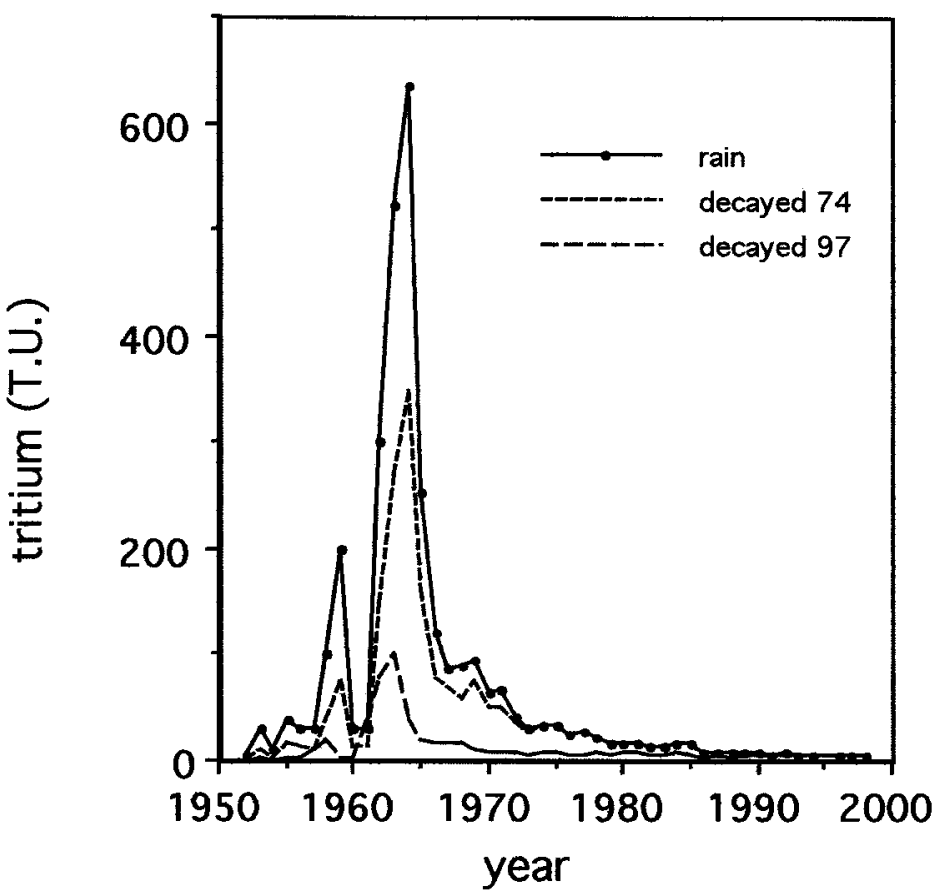

rain and their expected decayed values in groundwater for both 1974 and 1997, when groundwater samples were collected (modified after Yechieli et al. 1994). Note that the lower graph is an enlargement of the upper graph. Also shown are the values found in well Givat Brener in 1974 and 1997 (solid lines).

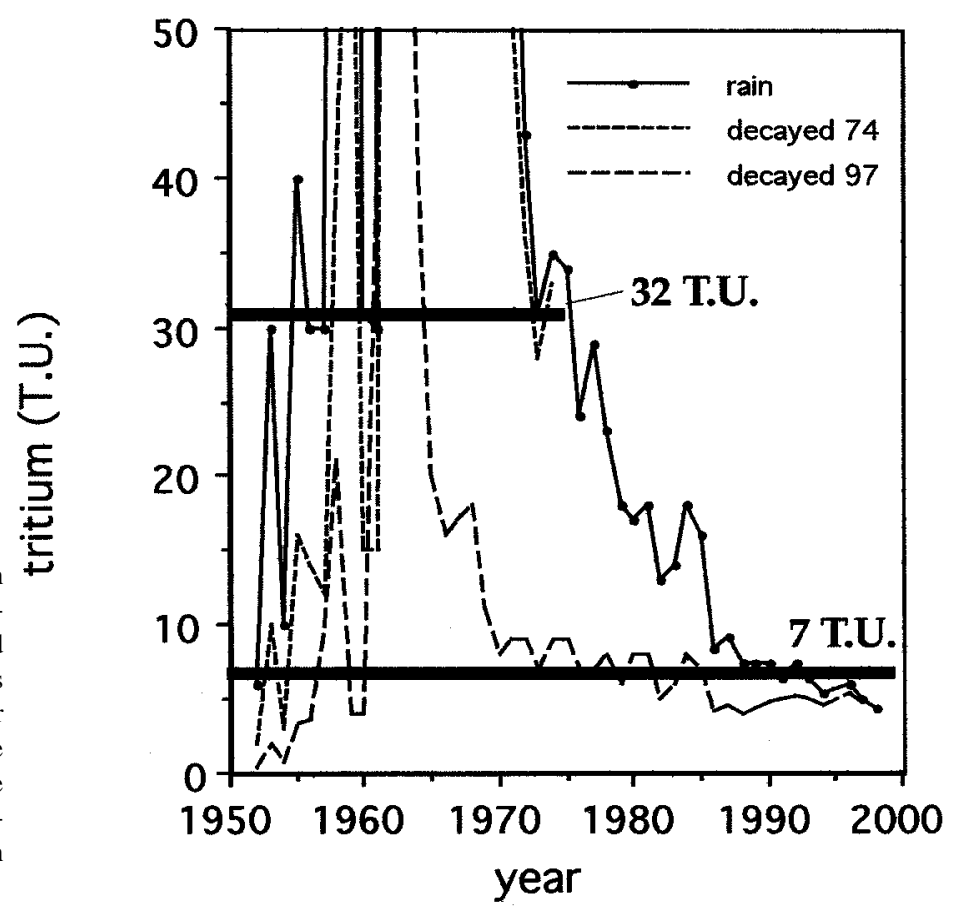




\section{CONCLUSIONS}

1. The spatial variation in the ${ }^{14} \mathrm{C}$ values between the eastern and western parts of the coastal aquifer of Israel may be explained by open and closed systems in the same aquifer.

2. The age estimates based on tritium and ${ }^{14} \mathrm{C}$ analyses may be improved if these analyses are repeated after an extended period of time.

\section{ACKNOWLEDGMENTS}

We thank I Carmi for the ${ }^{14} \mathrm{C}$ analysis of the 1990s samples, for the tritium analysis and for providing information of tritium concentration in rain in the last 5 years, B Cohen and N Shragai for preparing the figures, and $\mathrm{H}$ Hemo for his assistance with the sampling in the field.

\section{REFERENCES}

Clark ID, Fritz P. 1997. Environmental isotopes in hydrogereology. New York: Lewis Publishers. p 112-89, 200-31.

Dorr H, Sonntag C, Regenberg W. 1987 Field study on the initial ${ }^{14} \mathrm{C}$ content as a limiting factor in ${ }^{14} \mathrm{C}$ groundwater dating. IAEA-SM-299/38: 73-86.

Geyh MA, Wirth K. 1980. ${ }^{14} \mathrm{C}$ ages of confined groundwater from the Gwandu Aquifer, Sokoto Basin, northern Nigeria. Journal of Hydrology 48:281-8.

Gvirtzman G, Shachnai E, Bakler N, Ilani S. 1984. Stratigraphy of the Kurkar Group (Quarternary) of the Coastal Plain of Israel. Curr. Res. Geo. Surv. Isr.: 7082.

Issar A. 1968. Geology of the central coastal plain of Israel. Israel Journal of Earth-Sciences 17:16-29.

Leaney FW, Allison GB. 1986. Carbon-14 and stable isotope data for an area in the Murray Basin: its use in estimating recharge. Journal of Hydrology 88:129-45.

Levin I, Munnich KO, Weiss W. 1980. The effect of anthropogenic $\mathrm{CO}_{2}$ and ${ }^{14} \mathrm{C}$ sources on the distribution of ${ }^{14} \mathrm{C}$ in the atmosphere. Radiocarbon 22(2):379-91.

Mercado A, Avron M, Kahanovitch Y. 1975. Groundwa- ter salinity in the coastal plain - chloride inventory and assessment of future salinity trends. Tahal Report 01/ 75/88. In Hebrew.

Mook WG. 1980. Carbon-14 in hydrogeological studies. In: Fritz P, Fontes J-Ch, editors. Handbook of environmental isotope geochemistry. Volume 1. The terrestrial environment. New York: Elsevier Scientific Publishers. p 49-74.

Nativ R, Weisbrod N. 1994. Hydraulic connections among subaquifers of the Coastal Plain Aquifer, Israel. Groundwater 32(6):997-1007.

Rosensaft M, Ecker A, Levitte D, Ilani S, Shimron A, Rosenfeld A, Sneh A, Bein A. 1997. The three-dimensional configuration and lithological composition of the coastal aquifer and the unsaturated zone, Israel. Geological Survey of Israel Report GSI/15/95.

Wigley TML. 1975 Carbon 14 dating of groundwater from closed and open systems. Water Resources Research 11(2):324-8.

Yechieli Y, Ronen D, Kaufman A, Carmi I. 1994. New tritium data in waters of the Dead Sea area. Isr. J. Earth Sciences 43: 213-20. 